\title{
When to call it off: defining transplant candidacy limits in liver donor liver transplantation for hepatocellular carcinoma
}

Abu Bakar Hafeez Bhatti ${ }^{1 *}$ D, Ammal Imran Qureshi ${ }^{1}$, Rizmi Tahir ${ }^{1}$, Faisal Saud Dar ${ }^{1}$, Nusrat Yar Khan ${ }^{1}$, Haseeb Haider Zia', Shahzad Riyaz ${ }^{2}$ and Atif Rana ${ }^{3}$

\begin{abstract}
Background: Living donor liver transplantation (LDLT) is an acceptable treatment option for hepatocellular carcinoma (HCC). Traditional transplant criteria aim at best utilization of donor organs with low risk of post transplant recurrence. In LDLT, long term recurrence free survival (RFS) of 50\% is considered acceptable. The objective of the current study was to determine preoperative factors associated with high recurrence rates in LDLT.

Methods: Between April 2012 and December 2019, 898 LDLTs were performed at our center. Out of these, 242 were confirmed to have HCC on explant histopathology. We looked at preoperative factors associated with $\leq 50 \%$ RFS at 4 years. For survival analysis, Kaplan Meier curves were used and Cox regression analysis was used to identify independent predictors of recurrence.

Results: Median AFP was 14.4(0.7-11,326.7) ng/ml. Median tumor size was 2.8(range $=0.1-11) \mathrm{cm}$ and tumor number was 2(range $=1-15)$. On multivariate analysis, AFP $>600 \mathrm{ng} / \mathrm{ml}[\mathrm{HR}: 6, \mathrm{Cl}: 1.9-18.4, P=0.002]$ and microvascular invasion (MVI) [HR:5.8, Cl: 2.5-13.4, $P<0.001$ ] were independent predictors of 4 year RFS $\leq 50 \%$. When AFP was $>600 \mathrm{ng} / \mathrm{ml}$, MVI was seen in $88.9 \%$ tumors with poor grade and $75 \%$ of tumors outside University of California San Francisco criteria. Estimated 4 year RFS was $78 \%$ for the entire cohort. When AFP was $<600 \mathrm{ng} / \mathrm{ml}$, 4 year RFS for well-moderate and poor grade tumors was 88 and 73\%. With AFP > $600 \mathrm{ng} / \mathrm{ml}$, RFS was 53\% and 0 with well-moderate and poor grade tumors respectively $(P<0.001)$.
\end{abstract}

Conclusion: Patients with AFP $<600 \mathrm{ng} / \mathrm{ml}$ have acceptable outcomes after LDLT. In patients with AFP $>600 \mathrm{ng} / \mathrm{ml}$, a preoperative biopsy to rule out poor differentiation should be considered for patient selection.

Keywords: Microvascular invasion, AFP, Recurrence, UCSF criteria, Liver transplantation

\footnotetext{
* Correspondence: abubakar.hafeez@shifa.com.pk;

abubakar.hafeez@yahoo.com

'Division of Hepato-Pancreatico-Biliary Surgery and Liver Transplantation,

Shifa International Hospital, Islamabad, Pakistan

Full list of author information is available at the end of the article
}

(c) The Author(s). 2020 Open Access This article is licensed under a Creative Commons Attribution 4.0 International License, which permits use, sharing, adaptation, distribution and reproduction in any medium or format, as long as you give appropriate credit to the original author(s) and the source, provide a link to the Creative Commons licence, and indicate if changes were made. The images or other third party material in this article are included in the article's Creative Commons licence, unless indicated otherwise in a credit line to the material. If material is not included in the article's Creative Commons licence and your intended use is not permitted by statutory regulation or exceeds the permitted use, you will need to obtain permission directly from the copyright holder. To view a copy of this licence, visit http://creativecommons.org/licenses/by/4.0/ The Creative Commons Public Domain Dedication waiver (http://creativecommons.org/publicdomain/zero/1.0/) applies to the data made available in this article, unless otherwise stated in a credit line to the data. 


\section{Background}

Liver transplantation is an established treatment modality in patients with hepatocellular carcinoma (HCC) and cirrhosis [1, 2]. Milan criteria and University of California San Francisco (UCSF) criteria are the most widely accepted transplant criteria for patient selection $[3,4]$. These criteria have been primarily derived in the deceased donor liver transplant (DDLT) setting and aim at best utilization of donor organs. In living donor liver transplantation (LDLT), issues such as prolonged waiting times and competition for donor organs are not encountered. Thus, Milan and UCSF criteria appear restrictive. As a result, most LDLT centers in Asia perform LDLT for HCC outside these criteria [5].

The minimum acceptable recurrence free survi$\operatorname{val}(\mathrm{RFS})$ in the setting of LDLT remains debatable. Considering the operative risk to a living donor in LDLT, long term RFS of $50 \%$ is considered the benchmark [6, 7]. Other than tumor size and number; certain factors like AFP level, microvascular invasion (MVI) and poor grade have a significant impact on post transplant recurrence $[8,9]$. With a keen desire to increase patient pool eligible for transplantation, there is a need to identify patients who should be denied LDLT due to unacceptable recurrence risk.

We are a high volume LDLT center, and perform a significant number of transplants for HCC; some of whom are outside traditional transplant criteria. This provides a unique opportunity to assess outcomes in advanced tumors managed with LDLT.

In the setting of LDLT, long term RFS $<50 \%$ should be considered unacceptable and transplant in such patients should be considered futile. The objective of the current study was to identify preoperative factors, in the presence of which, LDLT can be potentially declined.

\section{Methods}

Between April 2012 and December 2019, a total of 898 living donor liver transplants were performed at our center. For this study we included adult patients with a diagnosis of $\mathrm{HCC}$ on explant histopathology who underwent LDLT between April 2012 and June $2019(n=242)$.

Details of diagnostic workup and patient selection for transplantation have been reported elsewhere [10, 11]. The diagnosis of HCC was made on a liver dynamic CT scan. A dynamic MRI scan of the liver was performed if CT scan findings were not conclusive. Biopsy was reserved for cases where diagnosis could not be established on dynamic imaging. All patients were discussed in multi disciplinary team meeting. Extra-hepatic metastasis and main portal vein tumor thrombosis were considered absolute contraindications for transplantation. Preoperative treatments including trans-arterial chemoembolization (TACE), radio-frequency ablation (RFA) and percutaneous ethanol injection (PEI) were discussed with all patients. With accumulating experience, patients with tumor size $>10 \mathrm{~cm}$, segmental or lobar portal vein tumor thrombus, or AFP $>1000 \mathrm{ng} / \mathrm{ml}$ were considered for down-staging, if feasible. In case there was an anticipated delay, these treatments were used as a bridge for transplantation.

We looked at patient demographics, AFP levels, etiology of liver failure, Model for end stage liver disease(MELD), and Child Turcot Pugh (CTP) scores, tumor variables, and preoperative treatment. Prognostic variables including Milan and UCSF criteria for transplantation, tumor grade, microvascular invasion, AFP, MELD and CTP score, graft to recipient weight ratio (GRWR), and preoperative treatment were assessed to determine impact on RFS. We used different AFP cutoff values for prognostication based on previous reports [11-13]. We classified 4 year RFS $>50 \%$ as acceptable while $\leq 50 \%$ as unacceptable RFS based on previous recommendations $[6,7]$.

Primary objective of the study was to identify preoperative factors associated with unacceptable recurrence rates in the setting of LDLT. The RFS was calculated by subtracting date of recurrence from date of transplantation. Univariate analysis was performed using Kaplan Meier survival curves and Log rank test was used to determine significance. Variables that were associated with RFS $<50 \%$ at 4 years were included in the multivariate Cox proportional hazard model. To determine AFP cutoff for recurrence, we used receiver operator curves (ROC). To increase transplant eligible patients, we aimed for high specificity on ROC curves as previously shown [14]. Prognostic groups were developed based on preoperative prognostic factors associated with $<50 \%$ RFS at 4 years. Chi square and Fischer test were used for categorical variables. A $P$ value $<0.05$ was considered statistically significant. All analysis was performed on Statistical package for the social sciences (SPSS version 20). The study was approved by the hospital ethics committee.

\section{Results}

\section{Patient characteristics}

Median age was 53(30-74) years. Median BMI was 25.2(15.4-40) $\mathrm{kg} / \mathrm{m}^{2}$. Median AFP was 14.4(0.7-11, 326.7) ng/ml. Median tumor size on explant was $2.8($ range $=0.1-11) \mathrm{cm}$. Mean number of tumor nodules was 2(range $=1-15$ ). Prior HCV and HBV exposure was present in $193(79.7 \%)$ and $49(20.2 \%)$ patients respectively as shown in Table 1 . Pre transplant TACE and/or RFA was performed in 56(23.1\%) patients. 
Table 1 Patient characteristics

\begin{tabular}{lll}
\hline & $\begin{array}{l}\text { Number } \\
(\boldsymbol{N}=242)\end{array}$ & Percent (\%) \\
\hline $\begin{array}{lll}\text { Gender } \\
\text { Males }\end{array}$ & 203 & 83.9 \\
Age group & & \\
$\leq 40$ & 14 & 5.8 \\
$40-50$ & 80 & 33 \\
$50-60$ & 113 & 46.7 \\
$>60$ & 35 & 14.5 \\
Etiology & & \\
HCV & 183 & 75.6 \\
HBV & 34 & 14 \\
HCV + HBV & 10 & 4.1 \\
HBV + HDV & 5 & 2 \\
Cryptogenic & 7 & 2.9 \\
Others & 3 & 1.2
\end{tabular}

Graft to recipient weight ratio

$\begin{array}{ll}<0.8 & 40 \\ >0.8 & 202\end{array}$

MELD score

$$
\leq 10
$$

$11-20$

21-30

$>31$

A

A 50

B 100

C 92

\section{Extent}

Within Milan 134

Within UCSF criteria

Outside UCSF criteria

Tumor nodules

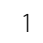

$$
2
$$$$
2
$$

3

Multiple

$\operatorname{AFP}(n g / m l)(N=232)$

$$
\begin{aligned}
& \text { Normal } \\
& \leq 600 \\
& >600
\end{aligned}
$$

Preoperative treatment

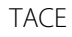

RFA
16.5

83.5

11.2

53.3

31.8

3.7

CTP class

20.7

41.3

$92 \quad 38$

16

92

118

56

50

74

136

22

54

11

Table 1 Patient characteristics (Continued)

\begin{tabular}{lll}
\hline & $\begin{array}{l}\text { Number } \\
(\boldsymbol{N}=242)\end{array}$ & Percent (\%) \\
\hline Grade & & \\
$\quad$ Well/moderate & 163 & 67.3 \\
Poor & 71 & 29.4 \\
Complete response & 8 & 3.3 \\
Micro vascular invasion & & \\
$\quad$ Present & 85 & 35.1 \\
\hline
\end{tabular}

\section{Prognostic factors associated with inferior 4 year RFS}

Estimated 4 year RFS was 78\% for the entire study cohort. Table 2 demonstrates 4 year RFS for various prognostic factors. An AFP cutoff of $40 \mathrm{ng} / \mathrm{ml}$ had sensitivity of $64 \%$ and specificity of $74 \%$ for recurrence. While AFP cutoff of

\begin{tabular}{|c|c|c|c|}
\hline Prognostic factors & & $\begin{array}{l}\text { Recurrence free } \\
\text { survival (\%) }\end{array}$ & $\boldsymbol{P}$ value \\
\hline \multirow[t]{2}{*}{ Milan criteria } & $\ln$ & 89 & $<0.0001$ \\
\hline & out & 53 & \\
\hline \multirow[t]{2}{*}{ UCSF criteria } & $\ln$ & 85 & 0.02 \\
\hline & out & 54 & \\
\hline \multirow[t]{2}{*}{ Number of tumors } & $\leq 3$ & 82 & 0.2 \\
\hline & $>3$ & 46 & \\
\hline \multirow{2}{*}{$\begin{array}{l}\text { Size of largest } \\
\text { tumor }(\mathrm{cm})\end{array}$} & $\leq 5$ & 82 & 0.004 \\
\hline & $>5$ & 62 & \\
\hline \multirow[t]{6}{*}{ AFP (ng/ml) } & $<600$ & 83 & $<0.0001$ \\
\hline & $>600$ & 30 & \\
\hline & $<1000$ & 79 & $<0.0001$ \\
\hline & $>1000$ & 45 & \\
\hline & $<2000$ & 78 & $<0.0001$ \\
\hline & $>2000$ & 41 & \\
\hline \multirow[t]{2}{*}{ Grade } & Well/moderate & 85 & 0.008 \\
\hline & poor & 61 & \\
\hline \multirow{2}{*}{$\begin{array}{l}\text { Microvascular } \\
\text { invasion }\end{array}$} & Absent & 90 & $<0.0001$ \\
\hline & present & 49 & \\
\hline \multirow{2}{*}{$\begin{array}{l}\text { Pretransplant } \\
\text { treatment }\end{array}$} & Not received & 86 & 0.01 \\
\hline & received & 54 & \\
\hline \multirow{2}{*}{$\begin{array}{l}\text { Graft to recipient } \\
\text { weight ratio }\end{array}$} & $>0.8$ & 80 & 0.1 \\
\hline & $<0.8$ & 74 & \\
\hline \multirow[t]{3}{*}{ CTP class } & A & 82 & 0.3 \\
\hline & $\mathrm{B}$ & 73 & \\
\hline & C & 84 & \\
\hline \multirow[t]{2}{*}{ MELD score } & $<20$ & 80 & 0.6 \\
\hline & $>20$ & 77 & \\
\hline
\end{tabular}
$600 \mathrm{ng} / \mathrm{ml}$ had a sensitivity of $35 \%$ and specificity of $97 \%$ for recurrence (AUC $=0.69, P<0.0001)$ (Fig. 1). AFP level

Table 2 Prognostic factors for estimated 4 year recurrence free survival 


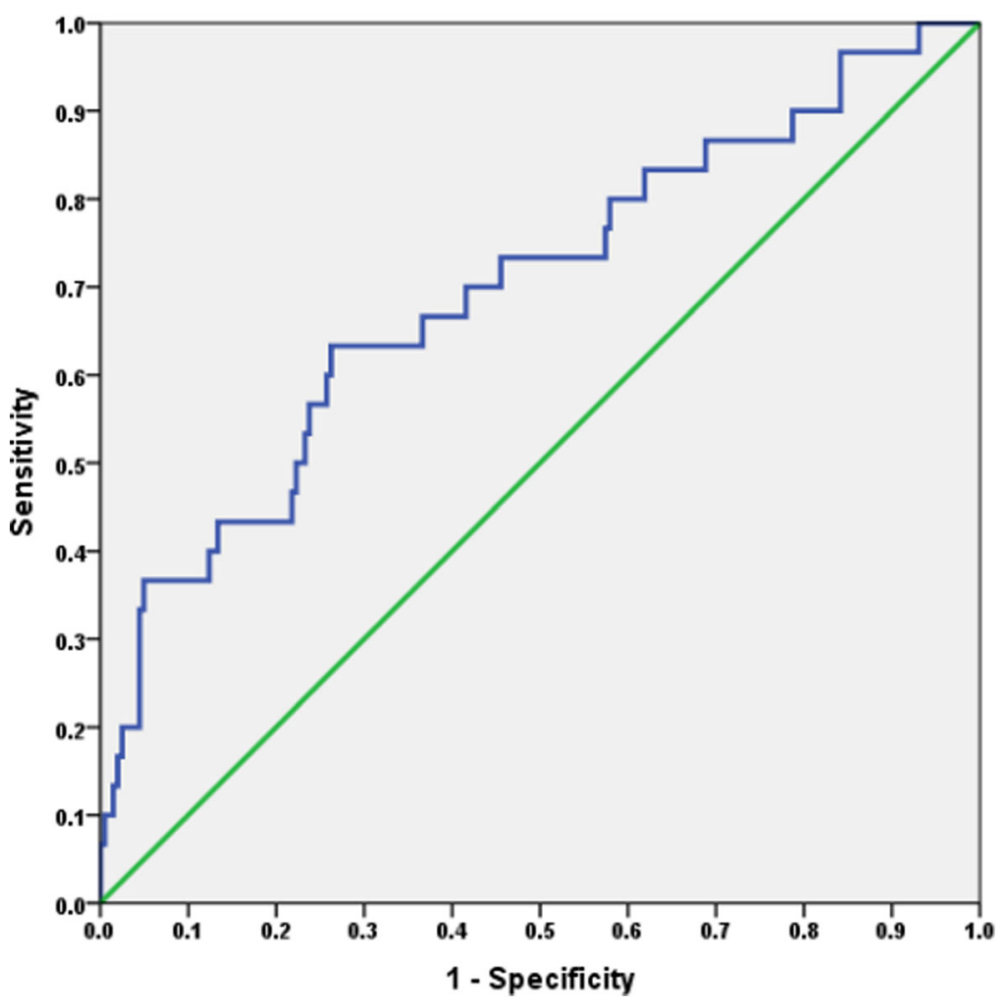

Fig. 1 ROC curve for AFP and HCC recurrence

and MVI were associated with $<50 \%$ RFS. The 4 year RFS was $30 \%$ versus $83 \%(P<0.001)$, $45 \%$ versus $79 \%(P<$ $0.001)$ and $41 \%$ versus $78 \%(P<0.001)$ for AFP cutoffs of $600 \mathrm{ng} / \mathrm{ml}, 1000 \mathrm{ng} / \mathrm{ml}$ and $2000 \mathrm{ng} / \mathrm{ml}$. In patients with MVI, 4 year RFS was $49 \%$ versus $90 \%(P<0.001)$.

A multivariate analysis including prognostic factors associated with 4 year RFS $<50 \%$ was performed as shown in Table 3. An AFP $>600 \mathrm{ng} / \mathrm{ml}$ and MVI were

Table 3 Multivariate analysis of risk factors associated with 4 year recurrence free survival $<50 \%$ on univariate analysis

\begin{tabular}{|c|c|c|c|}
\hline & \multicolumn{3}{|c|}{ Multivariate analysis } \\
\hline & Hazard ratio & Confidence interval & $\boldsymbol{P}$ value \\
\hline \multicolumn{4}{|c|}{ AFP (ng/ml) } \\
\hline$<600$ & 1 & $1.9-18.4$ & 0.002 \\
\hline$>600$ & 6 & & \\
\hline \multicolumn{4}{|c|}{ AFP (ng/ml) } \\
\hline$<1000$ & 1 & $0.4-13$ & 0.32 \\
\hline$>1000$ & 2.3 & & \\
\hline \multicolumn{4}{|c|}{ AFP (ng/ml) } \\
\hline$<2000$ & 1 & $0.59-16.4$ & 0.19 \\
\hline$>2000$ & 3.1 & & \\
\hline \multicolumn{4}{|c|}{ Microvascular invasion } \\
\hline absent & 1 & $2.5-13.4$ & $<0.0001$ \\
\hline present & 5.8 & & \\
\hline
\end{tabular}

independent predictors of RFS. Risk of recurrence was significantly increased with AFP $>600 \mathrm{ng} / \mathrm{ml}$ [HR:6, CI: 1.9-18.4, $P=0.002$ ] and MVI [HR:5.8, CI: 2.513.4, $P<0.001]$.The 4 year RFS in patients with combined AFP $>600 \mathrm{ng} / \mathrm{ml}$ and MVI was 0 versus $83 \%$ $(P<0.001)$ as shown in Fig. 2.

\section{Preoperative factors associated with MVI}

Since MVI cannot be accurately determined preoperatively, we looked for factors associated with high risk (>50\%) of MVI. When combined with AFP $>600 \mathrm{ng} / \mathrm{ml}$, tumors outside UCSF criteria and poor grade were significant factors associated with high risk of MVI as shown in Table 4.

Since AFP and MVI were the only independent predictors of $<50 \%$ RFS on multivariate analysis, we developed prognostic groups associated with high risk of MVI based on AFP $>600 \mathrm{ng} / \mathrm{ml}$. The highest risk of MVI was seen in patients with AFP $>600 \mathrm{ng} / \mathrm{ml}$ and poor grade (88.9\%) and AFP $>600 \mathrm{ng} / \mathrm{ml} / \mathrm{UCSF}$ out tumors $(75 \%)$ as shown in Table 5.

\section{Patient selection for LDLT}

Table 6 demonstrates actual recurrence rates in various prognostic groups. All patients with AFP $<600 \mathrm{ng} / \mathrm{ml}$ within and outside UCSF criteria, irrespective of tumor grade, had an acceptable 4 year RFS $(>50 \%)$ as shown in 


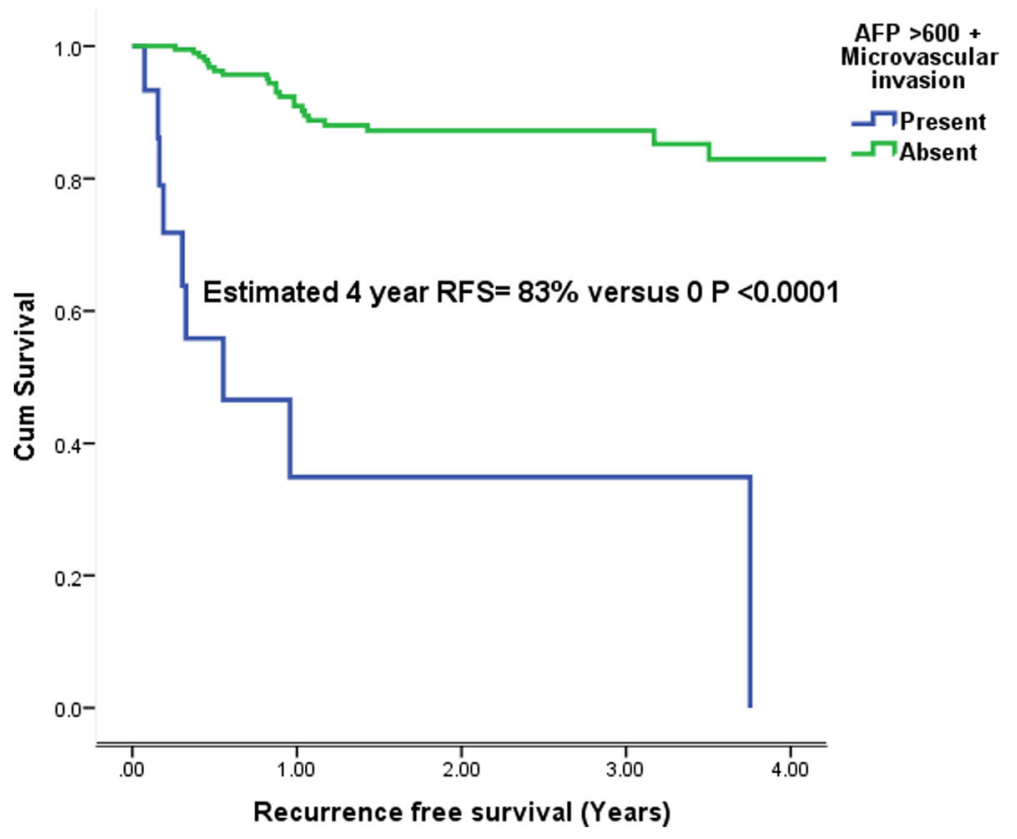

Fig. 2 Estimated 4 year recurrence free survival in patients with combined AFP $>600 \mathrm{ng} / \mathrm{ml}$ and microvascular invasion

Fig. 3. The estimated 4 year RFS in patients with AFP > $600 \mathrm{ng} / \mathrm{ml}$ irrespective of whether tumors were within or outside UCSF criteria was $<50 \%$ (Fig. 3a). In patients with AFP $>600 \mathrm{ng} / \mathrm{ml}, 4$ year RFS was $53 \%$ for well-moderately differentiated tumors while it was 0 and not reached with poorly differentiated tumors (Fig. 3b). When patients with AFP $>600 \mathrm{ng} / \mathrm{ml}$ and poor differentiation were excluded, the 4 year RFS of our patient cohort was $82 \%$.

Table 4 Rates of microvascular invasion with various prognostic variables

\begin{tabular}{|c|c|c|c|c|c|}
\hline & \multicolumn{2}{|c|}{$\begin{array}{c}\text { Microvascular Mic } \\
\text { invasion present } \\
\end{array}$} & \multicolumn{2}{|c|}{$\begin{array}{l}\text { crovascular } \\
\text { invasion absent }\end{array}$} & \multirow[b]{2}{*}{$P$ value } \\
\hline & Number & Percent & Number & Percent & \\
\hline AFP $>600 \mathrm{ng} / \mathrm{ml}$ & 15 & 68.1 & 7 & 31.9 & 0.001 \\
\hline Poor grade & 38 & 54.2 & 32 & 45.8 & $<0.0001$ \\
\hline Tumor size $>5 \mathrm{~cm}$ & 28 & 63.6 & 16 & 36.4 & $<0.0001$ \\
\hline Tumor size $>6.5 \mathrm{~cm}$ & 15 & 75 & 5 & 25 & $<0.0001$ \\
\hline Tumor number $>3$ & 28 & 56 & 22 & 44 & 0.001 \\
\hline $\begin{array}{l}\text { Tumors outside Milan } \\
\text { criteria }\end{array}$ & 54 & 52.9 & 48 & 47.1 & $<0.0001$ \\
\hline $\begin{array}{l}\text { Tumors outside UCSF } \\
\text { criteria }\end{array}$ & 48 & 55.8 & 38 & 54.2 & $<0.0001$ \\
\hline \multicolumn{6}{|c|}{ MVI with each variables when AFP $>600 \mathrm{ng} / \mathrm{ml}$} \\
\hline Poor grade & 8 & 88.9 & 1 & 11.1 & $<0.0001$ \\
\hline Tumor size $>6.5 \mathrm{~cm}$ & 3 & 75 & 1 & 25 & 0.1 \\
\hline Tumor number $>3$ & 5 & 71.4 & 2 & 28.6 & 0.05 \\
\hline UCSF out tumors & 9 & 75 & 3 & 25 & $<0.0001$ \\
\hline
\end{tabular}

\section{Discussion}

The current study reports outcomes of a significantly large cohort of patients who underwent LDLT for HCC $[9,14]$. A small percentage of patients $(<10 \%)$ had AFP $>600 \mathrm{ng} / \mathrm{ml}$. This group was further assessed for poor differentiation. Overall, $<5 \%$ patients had AFP $>600 \mathrm{ng} /$ $\mathrm{ml}$ with poor differentiation. We believe this is the group of patients with very high risk of recurrence and needs to be identified on preoperative biopsy.

We identified AFP and MVI as important prognostic variables for recurrence post transplantation. The prognostic impact of AFP and MVI is well known [8, 14-19]. The challenge remains in preoperatively identifying patients likely to have MVI. Various imaging modalities including computed tomography (CT), magnetic resonance imaging(MRI), positron emission tomography (PET) scan and tumor marker cutoffs have been assessed but remain inconsistent in detection of MVI [18-21].Preoperative biopsy is also not accurate in detecting MVI but carries sinister risk of tumor seeding [18]. This limits the widespread application of preoperative biopsy in transplant candidates and a cautious approach is warranted. Based on results of the current study, only $22 / 242(9 \%)$ patients would mandate a preoperative biopsy. Poor grade in this group would be a surrogate marker of MVI as 88.9\% patients had MVI when AFP $>600 \mathrm{ng} / \mathrm{ml}$ and poor grade were present together.

Role of preoperative biopsy in the diagnosis of HCC, in particular before transplantation remains less clear. The obvious advantage includes pertinent diagnostic and 
Table 5 Risk of Microvascular invasion based on AFP, UCSF criteria and poor grade prognostic groups

\begin{tabular}{|c|c|c|c|c|c|}
\hline & \multicolumn{2}{|c|}{ Microvascular invasion present } & \multicolumn{2}{|c|}{ Microvascular invasion absent } & \multirow[b]{2}{*}{$P$ value } \\
\hline & Number & Percent & Number & Percent & \\
\hline \multicolumn{6}{|l|}{ Group 1} \\
\hline AFP $>600+$ UCSF out & 9 & 75 & 3 & 25 & \multirow[t]{4}{*}{$<0.001$} \\
\hline AFP $>600+$ UCSF in & 6 & 60 & 4 & 40 & \\
\hline AFP $<600+$ UCSF out & 39 & 53.4 & 34 & 46.6 & \\
\hline AFP $<600+$ UCSF in & 31 & 22.1 & 109 & 77.9 & \\
\hline \multicolumn{6}{|l|}{ Group 2} \\
\hline AFP $>600+$ poor diff & 8 & 88.9 & 1 & 11.1 & \multirow[t]{4}{*}{$<0.001$} \\
\hline AFP $>600$ - poor diff & 7 & 53.9 & 6 & 46.1 & \\
\hline AFP $<600+$ poor diff & 30 & 50.8 & 29 & 49.2 & \\
\hline AFP $<600$ - poor diff & 40 & 26.5 & 111 & 73.5 & \\
\hline
\end{tabular}

prognostic information [22]. It has been shown that the diagnostic sensitivity and specificity of needle biopsy is 94 and $100 \%$ respectively [23]. The drawbacks include an invasive procedure, with risks of bleeding and tumor seeding, and inaccurate information. In recent times, with technical improvements, the risk of tumor seeding $(0.001 \%)$ and major complications appears $(0.004 \%)$ to have tremendously reduced and diagnostic errors are rare [24]. Moreover, better knowledge of molecular and immuno histochemical properties of HCC has led to renewed interest in the role of biopsy in patients with HCC [22, 25]. Poor grade has been used by the Toronto and Hangzhou group to select patients unlikely to benefit from transplantation $[8$, 17]. With Toronto criteria, 108/242(44.6\%) patients in the current study would require preoperative biopsy. With AFP $>600 \mathrm{ng} / \mathrm{ml}$ as the only indication, irrespective of tumor size and number, we have potentially limited preoperative biopsy to very few patients, increased the number of patient pool eligible for transplantation, and identified a subgroup which despite AFP $>600 \mathrm{ng} / \mathrm{ml}$ can be transplanted with acceptable risk of recurrence. In this group, LDLT should only be offered if well to moderate grade is confirmed preoperatively. A strict tumor size or number cutoff to select patients for preoperative biopsy can miss out on patients with high AFP and poor grade leading to unacceptable recurrence risk. We suggest that if poor grade is present in patients with AFP $>600 \mathrm{ng} / \mathrm{ml}$, LDLT should be potentially declined.

In recent years, increasingly complex criteria incorporating tumor size and number, yet relying heavily on biological factors have been proposed [26-29]. These are primarily based on DDLT experience and attempt to increase eligible transplant pool without compromising outcomes when compared with Milan criteria. However, it has been suggested that post transplant outcomes in patients who fulfill these criteria are not comparable to Milan criteria [28]. In the current study, we have attempted to identify eligible candidates with acceptable

Table 6 Recurrence in prognostic groups based on AFP, UCSF criteria and tumor grade

\begin{tabular}{|c|c|c|c|c|c|c|}
\hline & \multicolumn{2}{|c|}{ Recurrence } & \multicolumn{2}{|c|}{ No Recurrence } & \multirow[b]{2}{*}{ Total } & \multirow[b]{2}{*}{$\boldsymbol{P}$ value } \\
\hline & Number & $\overline{\text { Percent }}$ & Number & 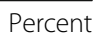 & & \\
\hline \multicolumn{7}{|l|}{ Group 1} \\
\hline AFP $>600+$ UCSF out & 6 & 50 & 6 & 50 & 12 & \multirow{4}{*}{$<0.001$} \\
\hline AFP $>600+$ UCSF in & 5 & 50 & 5 & 50 & 10 & \\
\hline AFP $<600+$ UCSF out & 11 & 13.5 & 70 & 86.5 & 81 & \\
\hline AFP $<600+$ UCSF in & 8 & 6.2 & 121 & 93.8 & 129 & \\
\hline \multicolumn{7}{|l|}{ Group 2} \\
\hline AFP $>600+$ poor diff & 6 & 66.7 & 3 & 33.4 & 9 & \multirow[t]{4}{*}{$<0.001$} \\
\hline AFP $>600$ - poor diff & 5 & 38.4 & 8 & 61.6 & 13 & \\
\hline AFP $<600+$ poor diff & 9 & 15.2 & 50 & 84.8 & 59 & \\
\hline AFP $<600$ - poor diff & 10 & 6.6 & 141 & 93.4 & 151 & \\
\hline
\end{tabular}



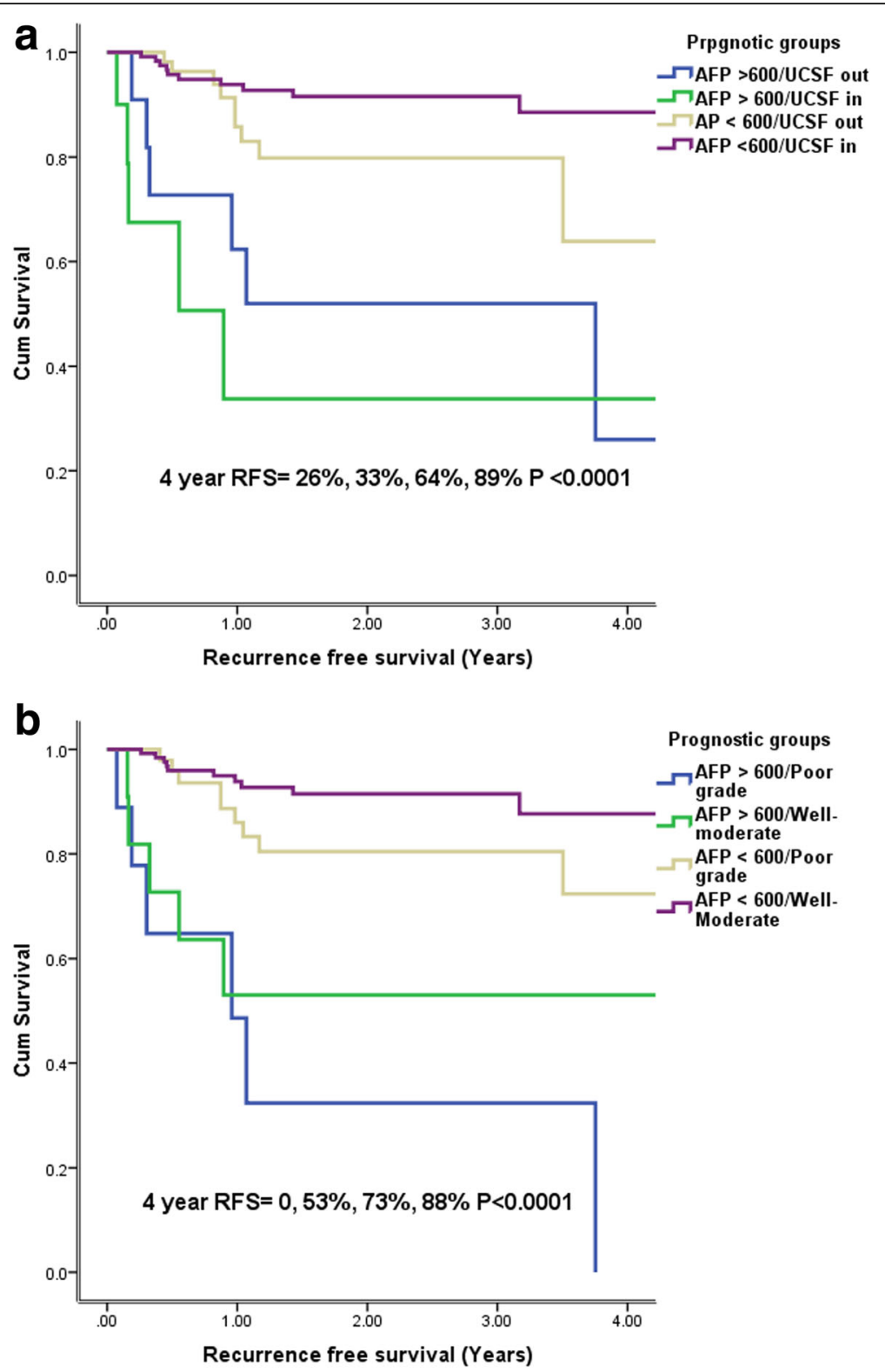

Fig. 3 a Estimated 4 year recurrence free survival based on AFP and UCSF criteria $\mathbf{b}$ based on AFP and tumor grade

(>50\%) RFS. The purpose is not achieve outcomes comparable to Milan criteria but to identify all patients who are eligible transplant candidates. This is more relevant to LDLT where there is no obvious benefit of comparing outcomes with non-HCC patients on the waiting list for liver transplantation. Moreover, we have done so using simple well established pretransplant variables that are easily available and applicable.

Worldwide, transplant criteria for HCC are becoming more inclusive, dynamic and biology driven [26, 30-34]. To improve identification of high risk HCC patients for LDLT, some centers have used des- gamma-carboxy prothrombin (DCP) and PET scan. Imaging modalities such as PET scans and tumors markers other than AFP still need validation in terms of their clinical applicability. It is important that patients with HCC in whom LDLT is essentially futile are identified using simpler models with easily applicable tools that have been previously validated to impact prognosis.

\section{Conclusion}

The current study uses well established preoperative variables in a large cohort of HCC patients who 
underwent LDLT, to identify patients at high risk of post transplant recurrence. Judicious use of preoperative biopsy in patients with AFP $>600 \mathrm{ng} / \mathrm{ml}$ can identify patients not suitable for transplantation. We believe, it is more relevant to LDLT setting, where liberal cutoffs are used on tumor dimensions, waiting time is short and competition for donor organs is absent. These results need to be validated in similar settings with longer follow up to determine applicability of current findings.

\section{Abbreviations}

AFP: Alpha fetoprotein; DDLT: Deceased donor liver transplantation; HCC: Hepatocellular carcinoma; LDLT: Living donor liver transplantation; MELD: Model for end stage liver disease; MVI: Microvascular invasion; NLR: Neutrophil to lymphocyte ratio; RFA: Radio frequency ablation; MWA: Microwave ablation; RFS: Recurrence free survival; TACE: Trans arterial chemo embolization; UCSF: University of California San Francisco

\section{Acknowledgements}

None.

\section{Authors' contributions}

AHB contributed to concept, design, analysis, drafting and critical review of the manuscript. AIQ and RT contributed to data collection, analysis and drafting. FSD and NYK contributed to concept, manuscript drafting and critical review. HHZ, SR and AR contributed to design, manuscript drafting and critical review. All authors have read and approved the final manuscript.

\section{Funding}

No funding was received.

\section{Availability of data and materials}

The datasets used during the current study are available from the corresponding author on reasonable request.

\section{Ethics approval and consent to participate}

The institutional review board and ethics committee of Shifa International Hospital/Shifa Tameer-e-Millat university approved the study (IRB \# 013-8332020). A written consent to participate was taken from patients.

\section{Consent for publication}

Not applicable.

\section{Competing interests}

The authors declare that they have no competing interests.

\section{Author details}

${ }^{1}$ Division of Hepato-Pancreatico-Biliary Surgery and Liver Transplantation, Shifa International Hospital, Islamabad, Pakistan. ${ }^{2}$ Division of Transplant Hepatology, Shifa International Hospital, Islamabad, Pakistan. ${ }^{3}$ Division of Radiology, Shifa International Hospital, Islamabad, Pakistan.

Received: 30 April 2020 Accepted: 29 July 2020

Published online: 12 August 2020

\section{References}

1. Song TJ, Ip EW, Fong Y. Hepatocellular carcinoma: current surgical management. Gastroenterology. 2004;127:S248-60.

2. Sapisochin G, Bruix J. Liver transplantation for hepatocellular carcinoma: outcomes and novel surgical approaches. Nat Rev Gastroenterol Hepatol. 2017;14:203-17.

3. Mazzaferro V, Regalia E, Doci R, et al. Liver transplantation for the treatment of small hepatocellular carcinomas in patients with cirrhosis. N Engl J Med. 1996;334:693-9.

4. Yao FY, Ferrell L, Bass NM, et al. Liver transplantation for hepatocellular carcinoma: expansion of the tumor size limits does not adversely impact survival. Hepatology. 2001;33:1394-403.
5. Lee SG. A complete treatment of adult living donor liver transplantation: a review of surgical technique and current challenges to expand indication of patients. Am J Transplant. 2015;15:17-38.

6. Lee KW, Yi NJ, Suh KS. Further expanding the criteria for HCC in living donor liver transplantation: when not to transplant: SNUH experience. Transplantation. 2014;8:S20-3.

7. Lee HW, Suh KS. Expansion of the criteria for living donor liver transplantation for hepatocellular carcinoma. Curr Opin Organ Transplant. 2016;21:231-7.

8. DuBay D, Sandroussi C, Sandhu L, et al. Liver transplantation for advanced hepatocellular carcinoma using poor tumor differentiation on biopsy as an exclusion criterion. Ann Surg. 2011;253:166-72.

9. Hong SK, Lee KW, Kim HS, et al. Living donor liver transplantation for hepatocellular carcinoma in Seoul National University. Hepatobiliary Surg Nutr. 2016:5:453-60

10. Dar FS, Bhatti ABH, Qureshi Al, et al. Living Donor Liver Transplantation in South Asia: Single Center Experience on Intermediate-Term Outcomes. World J Surg. 2018;42:1111-9.

11. Bhatti ABH, Dar FS, Qureshi Al, et al. Living donor liver transplantation for hepatocellular carcinoma: a single-center experience from Pakistan. J Clin Exp Hepatol. 2019:9:704-9.

12. Mehta N, Dodge JL, Roberts JP, et al. Alpha-Fetoprotein Decrease from > 1,000 to $<500 \mathrm{ng} / \mathrm{mL}$ in Patients with Hepatocellular Carcinoma Leads to Improved Post transplant Outcomes. Hepatology. 2019;69:1193-205.

13. Lai Q, lesari S, Melandro F, et al. The growing impact of alpha-fetoprotein in the field of liver transplantation for hepatocellular cancer: time for a revolution. Transl Gastroenterol Hepatol. 2017;16(2):72.

14. Kim SH, Moon DB, Kim WJ, et al. Preoperative prognostic values of afetoprotein (AFP) and protein induced by vitamin $\mathrm{K}$ absence or antagonist-II (PIVKA-II) in patients with hepatocellular carcinoma for living donor liver transplantation. Hepatobiliary Surg Nutr. 2016;5:461-9.

15. Shirabe K, Taketomi A, Morita K, et al. Comparative evaluation of expanded criteria for patients with hepatocellular carcinoma beyond the Milan criteria undergoing living-related donor liver transplantation. Clin Transpl. 2011;25: E491-8.

16. Kim JM, Kwon CH, Joh JW, P et al. Expanded criteria for liver transplantation in patients with hepatocellular carcinoma. Transplant Proc 2014; 46:726-729.

17. Zheng SS, Xu X, Wu J, et al. Liver transplantation for hepatocellular carcinoma: Hangzhou experiences. Transplantation. 2008:85:1726-32.

18. Cuccurullo V, Di Stasio GD, Mazzarella G, et al. Microvascular Invasion in HCC: The Molecular Imaging Perspective. Contrast Media Mol Imaging. 2018;9487938.

19. Fujiki M, Aucejo F, Choi M, et al. Neo-adjuvant therapy for hepatocellular carcinoma before liver transplantation: where do we stand? World J Gastroenterol. 2014;20:5308-19.

20. Haug AR. Imaging of primary liver tumors with positron emission tomography. Q J Nucl Med Mol Imaging. 2017;61:292-300.

21. Ahn SY, Lee JM, Joo I, et al. Prediction of microvascular invasion of hepatocellular carcinoma using gadoxetic acid enhanced MR and (18)F-FDG PET/CT. Abdom Imaging. 2015;40:843-51.

22. Russo FP, Imondi A, Lynch EN, Farinati F. When and how should we perform a biopsy for HCC in patients with liver cirrhosis in 2018? A review. Dig Liver Dis. 2018;50(7):640-6. https://doi.org/10.1016/j.dld.2018.03.014.

23. Guo Z, Kurtycz DF, Salem R, De Las Casas LE, Caya JG, Hoerl HD. Radiologically guided percutaneous fine-needle aspiration biopsy of the liver: retrospective study of 119 cases evaluating diagnostic effectiveness and clinical complications. Diagn Cytopathol. 2002;26(5):283-9. https:/doi.org/10.1002/dc.10097.

24. Wang P, Meng ZQ, Chen Z, et al. Diagnostic value and complications of fine needle aspiration for primary liver cancer and its influence on the treatment outcome-a study based on 3011 patients in China. Eur J Surg Oncol. 2008; 34(5):541-6. https://doi.org/10.1016/i.ejso.2007.07.013.

25. Zhang L, Cai Z, Rodriguez J, Zhang S, Thomas J, Zhu H. Fine needle biopsy of malignant tumors of the liver: a retrospective study of 624 cases from a single institution experience. Diagn Pathol. 2020;15(1):43. Published 2020 May 6. https://doi.org/10.1186/s13000-020-00965-5.

26. Duvoux C, Roudot-Thoraval F, Decaens T, et al. Liver transplantation for hepatocellular carcinoma: a model including a-fetoprotein improves the performance of Milan criteria. Gastroenterology. 2012;143:986-94.

27. Mazzaferro V, Sposito C, Zhou J, et al. Metroticket 2.0 model for analysis of competing risks of death after liver transplantation for hepatocellular carcinoma. Gastroenterology. 2018;154:128-39. 
28. Grat M, Stypułkowski J, Morawski M, et al. Shadows Behind Using Simple Risk Models in Selection of Hepatocellular Carcinoma Patients for Liver Transplantation. Ann Surg. 2018. [Epub ahead of print. https://doi.org/10. 1097/SLA.0000000000003176.

29. ChangY, Cho Y, Lee JH, et al. Comparison of Models for Tumor Recurrence after Liver Transplantation for the Patients with Hepatocellular Carcinoma: A Multicenter Long-Term Follow-Up Study. Cancers 2019; 11, 9 . pii: E1295. doi: https://doi.org/10.3390/cancers11091295.1295.

30. Kaido T, Ogawa K, Mori A, et al. Usefulness of the kyoto criteria the Kyoto criteria as expanded selection criteria for liver transplantation for hepatocellular carcinoma. Surgery. 2013;154:1053-60.

31. Lee SD, Lee B, Kim SH, et al. Proposal of new expanded selection criteria using total tumor size and (18)F-flourodeoxyglucose-positron emission tomography/computed tomography for living donor liver transplantation in patients with hepatocellular carcinoma: The National Cancer Center Korea criteria. World J Transplant. 2016;24:411-22.

32. Lee $\mathrm{H}$, Cho Y, Kim HY, et al. Serum tumor markers provide refined prognostication in selecting liver transplantation candidate for hepatocellular carcinoma patients beyond the Milan criteria. Ann Surg. 2016;263:842-50

33. Notarpaolo A, Layese R, Magistri P, et al. Validation of the AFP model as a predictor of $\mathrm{HCC}$ recurrence in patients with viral hepatitis-related cirrhosis who had received a liver transplant for HCC. J Hepatol. 2017;66:552-9.

34. Giard JM, Mehta N, Dodge JL, Roberts JP, Yao FY. Alpha-Fetoprotein Slope $>7.5 \mathrm{ng} / \mathrm{mL}$ per Month Predicts Microvascular Invasion and Tumor Recurrence After Liver Transplantation for Hepatocellular Carcinoma. Transplantation. 2018;102:816-22.

\section{Publisher's Note}

Springer Nature remains neutral with regard to jurisdictional claims in published maps and institutional affiliations.

Ready to submit your research? Choose BMC and benefit from:

- fast, convenient online submission

- thorough peer review by experienced researchers in your field

- rapid publication on acceptance

- support for research data, including large and complex data types

- gold Open Access which fosters wider collaboration and increased citations

- maximum visibility for your research: over $100 \mathrm{M}$ website views per year

At $\mathrm{BMC}$, research is always in progress.

Learn more biomedcentral.com/submissions 